\title{
Immobilization and stability studies of a lipase from thermophilic Bacillus sp: The effect of process parameters on immobilization of enzyme
}

\author{
Neerupma Nawani \\ Department of Biotechnology \\ Panjab University \\ Chandigarh 160014, India \\ Rajvinder Singh \\ Department of Biotechnology \\ Panjab University \\ Chandigarh 160014, India \\ E-mail: rajvindersingh00@rediffmail.com \\ Jagdeep Kaur* \\ Department of Biotechnology \\ Panjab University \\ 160014, Chandigarh, India \\ Tel: 00911722534086 \\ Fax: 00911722541409 \\ Email: jagsekhon@yahoo.com
}

\begin{abstract}
Financial support: Junior Research Fellowship to N.N. from Council of Scientific and Industrial Research, India and research grant to J.K.
\end{abstract} from Department of Biotechnology, India.

Keywords: esterification, immobilization, lipase, thermostability.

A thermostable lipase was partially purified from the culture supernatant of a thermophilic Bacillus sp. The enzyme is optimally active at $60^{\circ} \mathrm{C}$ and $\mathrm{pH} \mathrm{8.0}$. The enzyme showed enhancement in activity in presence of benzene or hexane $(30 \% \mathrm{v} / \mathrm{v}$ each). The activity (assayed by determining the release of $\mathrm{pNP}$ from pNP laurate) was stimulated up to $60 \%$ of these solvents in enzyme reaction mixture. The catalytic properties of this thermostable enzyme can be further improved via the use of different immobilization techniques and reaction conditions. Enzyme was immobilized on different solid supports and their enzyme activity and stability was compared. The enzyme was adsorbed on silica and HP20 beads followed by cross-linking with gluteraldehyde on HP-20, which improved the thermostability of enzyme. The optimum pH (pH 8.5) was nearly same for aqueous and immobilized enzyme while optimum temperature was nearly $5^{\circ} \mathrm{C}$ higher in case of immobilized enzyme. The immobilized/cross linked enzyme was more thermostable at 70 and $80^{\circ} \mathrm{C}$ in comparison to aqueous and surface adsorbed lipase on silica and HP-20. The optimum temperature for esterification reactions was determined to be $60-65^{\circ} \mathrm{C}$. Half-life of immobilized lipase was nearly $2.5 \mathrm{x}$ higher than the aqueous enzyme at $70^{\circ} \mathrm{C}$. Esterification of methanol and oleic acid to methyl oleate by immobilized enzyme was studied in detail.
Lipases, as a class of enzymes, are stable and extremely valuable catalysts for many practical/industrial applications (Bjorkling et al. 1991). They have been used to generate chiral entities from alcohols, carboxylic acid esters, cyanohydrins, chlorohydrins, diols, amines, diamines and amino alcohols (Jaeger et al. 1999), which are used as building blocks for a variety of pharmaceuticals and other fine chemicals. Many lipases are only moderately stable at high temperature and $\mathrm{pHs}$, that can influence their usefulness in some interesting reactions. Using lipases from thermophilic microorganisms, whose resistance to drastic conditions has been developed by nature, can solve this problem. At present, the majority of the thermophilic lipases that have been purified and characterized are obtained from Bacillus sp (Kim et al. 1994). To use these enzymes for industrial purposes, the most desirable step is to improve the features of biological catalyst to suit the industrial demand. The majority of current biocatalytic approaches rely on either using free enzyme in solution or living cells, which complicates product separation from the catalyst. The lipase immobilization may improve the stability and ease of product separation/reuse of enzyme. Although a variety of approaches exist for the immobilization of enzymes, the "science" of enzyme immobilization is still in its infancy. Several solid supports have been used for the purpose till now (Aucoin et al. 2004; Hwang et al. 2004; Palomo et al. 2004).

*Corresponding author 
Table 1. Immobilization of Lipase on different solid supports.

\begin{tabular}{|c|c|c|c|}
\hline \multirow{2}{*}{ S No. } & \multirow{2}{*}{ Solid supports } & Enzyme activity bound & Immobilized lipase \\
\cline { 3 - 4 } & & (\% of total enzyme activity added $)$ & Units $\mathrm{g}^{-1}$ of support \\
\hline 1 & HP-20 (CL) & 79 & 180.96 \\
\hline 2 & Silica & 76 & 163.63 \\
\hline 3 & HP-20 & 78 & 180.00 \\
\hline Control $=68.48$ Unit $\mathrm{ml}^{-1}$. & & \\
\hline
\end{tabular}

A novel thermophilic Bacillus sp has been isolated that produced a thermostable lipase from hot springs of Himachal Pradesh, India (Nawani et al. 2006). Hexane is the preferred solvent in most of the trans-esterification reactions. This enzyme is quite stable in hexane. In the present investigation attempts have been made to further improve the catalytic properties of the enzyme via the use of different immobilization techniques and reaction conditions. Dosanjh and Kaur (2002) earlier reported that HP-20 acts as a good support for immobilization of a lipase In the present investigation HP-20 was used as an immobilization support for this thermostable lipase and immobilized lipase was tested for advantageous catalytic property and stability.

\section{MATERIALS AND METHODS}

The culture (isolated Bacillus $s p$ ) was grown under optimal conditions for lipase production. A series of $500 \mathrm{ml}$, Erlenmeyer flasks containing $100 \mathrm{ml}$ wheat bran and nutrient broth medium, $(1 \% \mathrm{w} / \mathrm{v}$ each $) \mathrm{pH} 8.0$ were seeded with $2 \%$ inoculum and incubated at $60^{\circ} \mathrm{C}$ for $48 \mathrm{hrs}$ (Nawani et al. 2006). The culture was then centrifuged at $10,000 \mathrm{rpm}$ to remove the cells. The clear supernatant containing the lipase was used for further studies.

\section{Enzyme assay}

The activity was determined according to the method of Sigurgisladottir et al. (1993) with slight modification. To $0.8 \mathrm{ml}$ of $0.05 \mathrm{M}$ phosphate buffer ( $\mathrm{pH} 8.0$ ), $0.1 \mathrm{ml}$ enzyme and $0.1 \mathrm{ml} 0.01 \mathrm{M}$ pNP-laurate (Sigma, USA) was added. The reaction was carried out at $60^{\circ} \mathrm{C}$ for $30 \mathrm{~min}$, after which $0.25 \mathrm{ml} 0.1 \mathrm{M} \mathrm{Na}_{2} \mathrm{CO}_{3}$ was added. The mixture was centrifuged and the activity was determined at $420 \mathrm{~nm}$. One unit of lipase activity is defined as the amount of enzyme, which liberates $1 \mu \mathrm{g}$ of $\mathrm{p}$-Nitrophenol from pNP laurate as substrate in 30 min under standard assay conditions.

\section{Partial purification of enzyme}

Ammonium sulphate precipitation. To $900 \mathrm{ml}$ of the culture supernatant, ammonium sulphate was added $(70 \%$ saturation) at $4^{\circ} \mathrm{C}$. The precipitate was collected by centrifugation at $12000 \mathrm{x} \mathrm{g}$ at $4^{\circ} \mathrm{C}$ for $20 \mathrm{~min}$ and dissolved in $0.05 \mathrm{M}$ phosphate buffer ( $\mathrm{pH} 8.0)$. The lipase activity and the protein concentration (Lowry et al. 1951) were determined.

Hydrophobic interaction chromatography. The precipitated enzyme $(276 \mathrm{ml})$ was loaded on Phenyl Sepharose (Sigma) column $(4.0 \times 4.5 \mathrm{~cm})$ pre-equilibrated with $0.05 \mathrm{M}$ phosphate buffer ( $\mathrm{pH} 8.0)$. It was washed with

Table 2. Retention of immobilized lipase activity on solid supports after different cycles.

\begin{tabular}{|c|c|c|c|c|c|c|}
\hline \multirow{2}{*}{ S. No. } & Solid & \multicolumn{5}{|c|}{ Residual enzyme activity (\%) after } \\
\cline { 2 - 7 } & Supports & 5 cycles & 10 cycles & 15 cycles & 20 cycles & 25 cycles \\
\hline 1 & HP 20 & 100 & 93 & 86 & 79 & 71 \\
\hline 2 & Silica & 100 & 89 & 78 & 58 & 46 \\
\hline
\end{tabular}


$0.05 \mathrm{M}$ phosphate buffer ( $\mathrm{pH}$ 8.0) followed by $1 \mathrm{mM}$ phosphate buffer $(\mathrm{pH} 8.0)$. The enzyme was eluted with $40 \%$ ethylene glycol $(80 \mathrm{ml})$ in $1 \mathrm{mM}$ phosphate buffer $(\mathrm{pH}$ 8.0). Eight-ml fractions were collected and analyzed for lipase activity. Fractions with high lipase activity were pooled. The enzyme was concentrated by filtration through $10 \mathrm{kDa}$ cut off membrane filters.

\section{Effect of organic solvents on enzyme activity}

To study the effect of organic solvents on aqueous enzyme activity, organic solvents such as methanol, ethanol, acetone, Dimethylsulphoxide (DMSO), glycerol, polyethyleneglycol, hexane, benzene $(10 \%, 30 \% \mathrm{v} / \mathrm{v})$ were added to the reaction mixture and the lipase activity was determined under standard assay conditions. The sample without any additive was taken as control (100\%). The reaction mix with respective additives but without enzyme served as control. In addition enzyme was assayed in the presence of $60 \%$ of hexane or benzene in reaction mixture.

\section{Immobilization}

Adsorption kinetics of protein and lipase activity on solid support. Silica (Merck) and HP-20 beads (Diaion) were used for immobilization. HP-20 is aromatic in chemical structure (surface area ca. $600 \mathrm{~m}^{2} / \mathrm{g}$, pore radius 200-300 A), widely used for adsorption.

Silica. $5 \mathrm{ml}$ of partially purified enzyme was mixed with 1 $\mathrm{g}$ of silica in duplicate. These were left at room temperature for $90 \mathrm{~min}$ with intermittent mixing. After different time points $(0-90 \mathrm{~min})$ fractions were taken out and centrifuged at $1000 \mathrm{~g}$ for $5 \mathrm{~min}$. Supernatant was tested for unbound protein and enzyme activity. For esterification studies the silica was washed three times with $50 \mathrm{mM}$ phosphate $(\mathrm{pH}$ 8.0) buffer before use.

HP-20 beads. 1g of HP-20 was first washed with distilled water, then washed for $30 \mathrm{~min}$ with isopropyl alcohol and further washed three times with distilled water to remove isopropyl alcohol traces. The half of the washed beads were used as such and rest half was treated with $2.5 \%$ gluteraldehyde for $1 \mathrm{hr}$. The resin was washed 3 times with distilled water to remove residual gluteraldehyde. $5 \mathrm{ml}$ of enzyme was added to the resin and left on shaker for 90 min. After different time points $(0-90 \mathrm{~min})$ fractions were taken out and centrifuged at $1000 \mathrm{~g}$ for $5 \mathrm{~min}$. Supernatant was tested for unbound protein and enzyme activity. For esterification studies HP-20 beads were washed thrice in 50 $\mathrm{mM}$ phosphate buffer and used for the experiment.

\begin{tabular}{|c|c|c|c|}
\hline $\begin{array}{l}\text { Amount of lipase bound } \\
\text { to solid support }\end{array}$ & $=$ & $\begin{array}{l}\text { Total lipase present } \\
\text { in the binding medium }\end{array}$ & $\begin{array}{l}\text { Remaining lipase present } \\
\text { in the binding medium after } \\
\text { removal of solid support }\end{array}$ \\
\hline
\end{tabular}

Adsorbed lipases on different solid supports were assayed to define the adsorption capacity. Hundred $\mathrm{mg}$ of silica and HP-20 support (with and without cross-linking) with immobilized lipase was added into assay mixture and
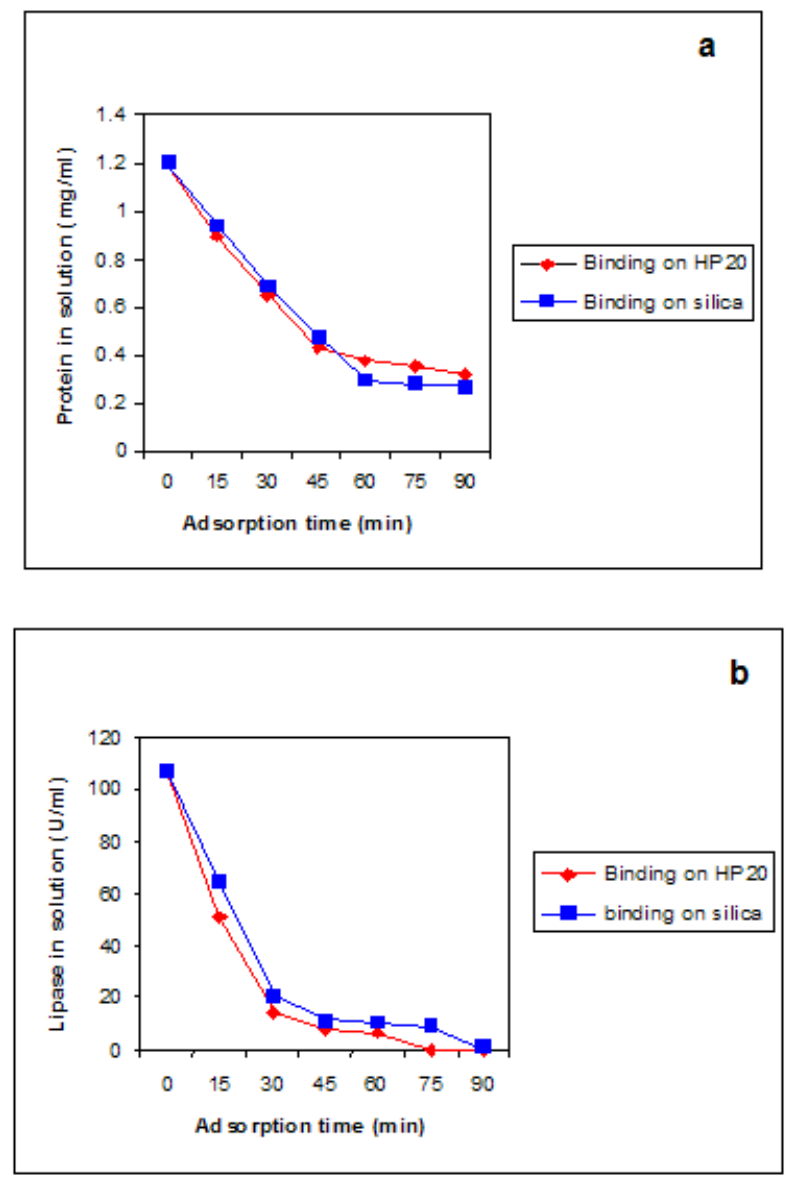

Figure 1. Adsorption kinetics on silica and HP-20.

(a) Time course of protein.

(b) Time course of lipase.

assayed with continuous shaking for $30 \mathrm{~min}$ as per standard method. The enzyme activity bound on each support was determined.

Retention of activity by immobilized lipase in continuous cycles. The immobilized enzymes were assayed by the method of Sigurgisladottir et al. (1993) for 25 cycles of $30 \mathrm{~min}$ each. For each cycle two $\mathrm{ml}$ of reaction mixture containing substrate was added to the immobilized support and incubated for $30 \mathrm{~min}$ with continuous shaking at $60^{\circ} \mathrm{C}$. The contents were then centrifuged and the supernatant was used for measuring absorption at $420 \mathrm{~nm}$. The pellet washed thrice with the $0.05 \mathrm{M}$ phosphate buffer $(\mathrm{pH} 8.0)$ and then used for the next cycle in similar manner.

Thermo-inactivation of free and immobilized lipase. To study the effect of temperature on free, immobilized and immobilized cross-linked lipase, different forms of enzymes were incubated at different temperatures $(60,70$ and $80^{\circ} \mathrm{C}$ ) for $1 \mathrm{hr}$ in $50 \mathrm{mM}$ Tris- $\mathrm{HCl} \mathrm{pH} \mathrm{8.0.} \mathrm{Residual}$ lipase activity was determined under standard assay conditions. Residual activity in the samples without incubation (incubated at $4^{\circ} \mathrm{C}$ ) was taken as $100 \%$. 


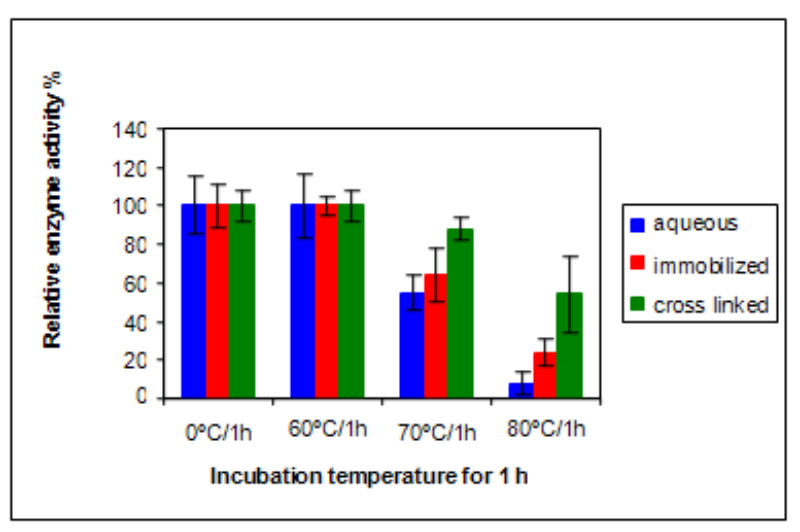

Figure 2. Effect of temperature on aqueous, immobilized and immobilized cross linked lipase.

To determine the half life of lipase, free $(80 \mathrm{U} / \mathrm{ml})$ and immobilized $(180 \mathrm{U} / \mathrm{g})$ lipase was incubated at $70^{\circ} \mathrm{C}$ for 8 hrs. After different time periods, fractions of free $(100 \mu \mathrm{l})$ and immobilized enzymes ( $100 \mu \mathrm{l}$ sample having $50 \mathrm{mg}$ of HP-20) were withdrawn and residual lipase activity was determined under standard assay conditions. Residual activity in the samples without incubation (incubated at $40^{\circ} \mathrm{C}$ ) was taken as $100 \%$.

Effects of $\mathrm{pH}$ and temperature on enzyme activity. Lipase activity was assayed in the buffers of different $\mathrm{pH}$ (4.5-11.0) at $60^{\circ} \mathrm{C}$. The residual lipase activity was determined by standard assay method.

The optimum temperature of lipase activity was determined by carrying out the enzyme reactions at different temperatures $\left(30-80^{\circ} \mathrm{C}\right)$ and $\mathrm{pH} 8.0$. The enzyme activity at the start of the experiment was taken as $100 \%$ and the residual lipase activity after incubation was determined.

\section{Esterification studies by aqueous and immobilized lipase}

For comparative study, aqueous and immobilized enzymes were used as biocatalysts for the esterification of oleic acid $(0.25 \mathrm{M})$ and methanol $(0.4 \mathrm{M})$ in hexane. The reaction was carried out at particular temperature with shaking for particular time with inactivated enzyme as a control. To 10 $\mathrm{ml}$ reaction mixture, $20 \mathrm{ml}$ acetone: methanol 1:1(v/v) was added. The ester content was quantified by using alkalimetric method of titrating unreacted acid with $0.1 \mathrm{~N}$ $\mathrm{NaOH}$ using phenolphthalein as an indicator. The conversion (\%) in ester synthesis was based on acid consumed (Bovora et al. 1993).

Time course of esterification. To determine the optimum time for the formation of methyl oleate from methanol and oleic acid by immobilized enzyme, the esterification reaction was carried out for different time points. The ester synthesis was analyzed as above.
Effect of temperature on esterification reaction. The optimum temperature for the formation of methyl oleate from methanol and oleic acid by immobilized enzyme, the esterification reaction was carried out at different temperatures $\left(50-85^{\circ} \mathrm{C}\right)$. The ester synthesis was analyzed as above

\section{RESULTS AND DISCUSSION}

\section{Basic characteristics of free lipase}

The strain was identified as Bacillus sp. based on characteristics such as aerobic growth, gram positive, rod shaped, motile, spore forming and catalase positive (Clans and Berkley, 1986). The organism could hydrolyze starch, casein and gelatin. It did not require sodium chloride and potassium chloride for growth. It was oxidase negative in nature and it did not produce any gas with glucose. On comparison of this Bacillus sp isolate with Bacillus stearothermophilus and other thermophilic Bacillus $s p$. (according to Bergey's manual), it showed the following different characteristics i.e. nitrate reduction, acid formation with arabinose, xylose and mannitol, casein hydrolysis, and no growth below $50^{\circ} \mathrm{C}$.

The lipase was partially purified by ammonium sulphate precipitation followed by Phenyl-Sepharose column chromatography (specific activity $160 \mathrm{U} / \mathrm{mg}$ protein). This partially purified enzyme was used for immobilization. As to the effect of organic solvents on enzyme activity, benzene and hexane had a highly stimulatory effect on the lipase activity (195 and 180\% respectively). The activity of enzyme was stimulated up to $60 \%$ of hexane/benzene in

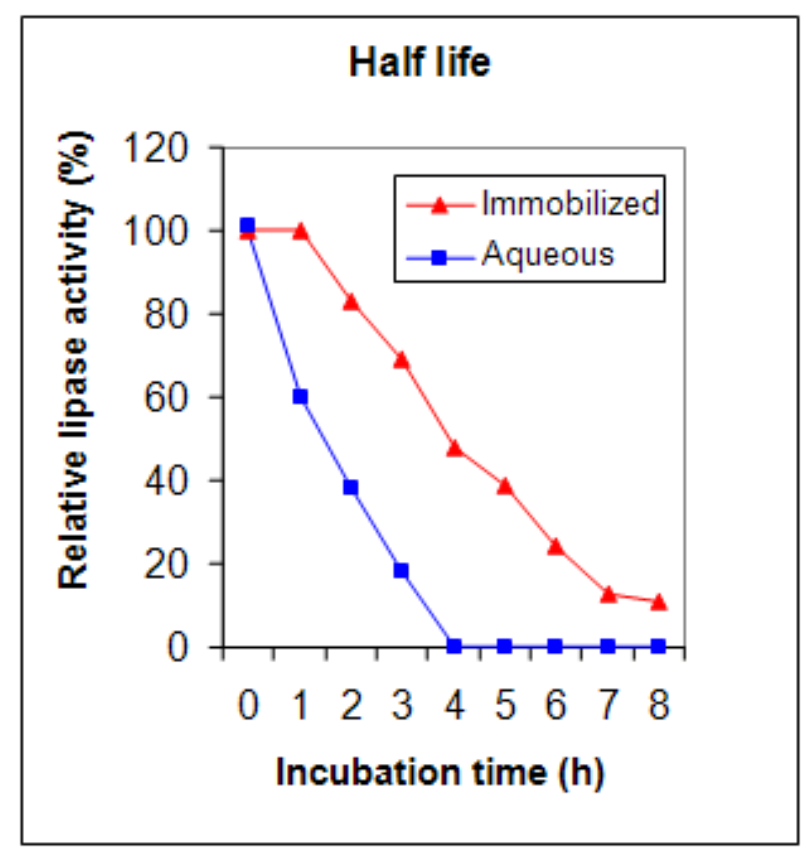

Figure 3. Determination of half-life of aqueous and immobilized lipase (HP-20). 


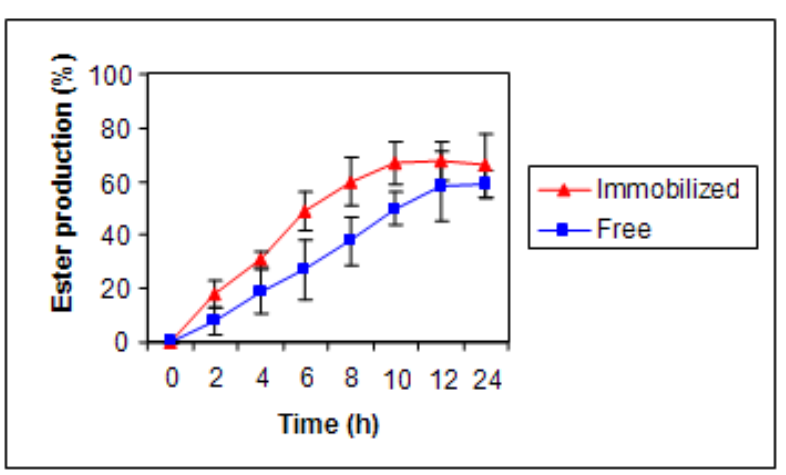

Figure 4. Time course of esterification of methanol and oleic acid by lipase at $60^{\circ} \mathrm{C}$. The amount of immobilized enzyme used was $180 \mathrm{U} / \mathrm{mg}$ solid support. The reaction was carried out for $24 \mathrm{hrs}$.

reaction mixture. The enzyme activity was slightly stimulated up to $30 \%$ in presence of acetone. DMSO (Dimethylsulphoxide) and ethylene glycol had almost no effect, while ethanol, methanol and propanol inhibited the enzyme activity. The effect of organic solvents might be attributed to the water content in reaction mix. Water plays a significant role in the activity of the enzymes (Klibanov, 1989). The inhibition of lipase in presence of ethanol, methanol while stimulation in water immiscible solvents confirms that polar water miscible solvents are more destabilizing than the water immiscible solvents (Fernández-Lorente et al. 2001). On the other hand effect of acetone on enzyme activity could not be explained by this theory.

\section{Immobilization of lipase}

The immobilization by ionic or physical adsorption was one of the simple and cheap methods to prepare an immobilized enzyme, although adsorbed enzymes were rather susceptible to desorption from the carrier (Rua and Ballesteros, 1994). Immobilization of isolated Bacillus sp lipase was carried out on HP-20 and Silica. The adsorption of lipase on various supports was determined by estimating the amount of lipase bound to the solid supports (Table 1). It was found that good adsorption was seen in HP 20 (with and without cross linking) and silica, where attachment to lipase was up to the extent of 78,79 and $86 \%$ respectively. The kinetics of protein and lipase adsorption to silica and HP-20 indicate that the amount of protein and lipase was well below saturation (Figure 1a) while no unbound lipase could be traced (Figure 1b). The protein and lipase adsorption was fast and maximum binding was observed after $45 \mathrm{~min}$ for protein and $30 \mathrm{~min}$ for lipase. This suggests that lipase is fast adsorbing protein amongst other proteins. The hydrophobic nature of solid substrate suggests that adsorption of proteins are governed by hydrophobic interactions. Rua and Ballesteros (1994) used moderately hydrophobic support (Phenyl Agarose) in the purification of lipase from C. rugosa. Similar hydrophobic adsorption supports were used by other workers for immobilization (Aucoin et al. 2004; Palomo et al. 2004). Continuous assay of residual enzyme activity in the lipase immobilized to HP-20 and silica was performed to find out the retention of lipase activity by each support over 25 cycles of enzyme reaction. Less desorption or leaching of the bound enzyme in case of HP-20 cross-linked might be due to very tight binding of the lipase on the hydrophobic supports, (Table 2). The lipase immobilized on HP-20 without cross-linking behaved like silica (data not shown) and in both the cases the leaching of enzyme activity was observed. Lipase immobilized on silica might be lost from the system because of de-sorption, severing of chemical bonds or erosion of the support material. For clear presentation of results only enzyme immobilized on silica is compared with HP-20 cross-linked. Similar to our observations, Fernández-Lorente et al. (2001) could use the immobilized lipase using hydrophobic moieties for 10 esterification cycles without any significant decrease in enzyme biocatalyst.

\section{Physico-chemical characterization and thermal stability of immobilized lipase}

No change in optimum $\mathrm{pH}$ for lipase activity was observed in the case of aqueous and immobilized form. Optimum temperature of immobilized (CL) enzyme shifted from $60^{\circ} \mathrm{C}$ to $65^{\circ} \mathrm{C}$. Yang and Rhee (1992) reported big shift in optimum reaction temperature from $37^{\circ} \mathrm{C}$ for the free lipase to $50^{\circ} \mathrm{C}$ for immobilized lipase. Effect of temperature on aqueous, immobilized and immobilized cross-linked lipase was further analyzed. Figure 2 demonstrates that the thermal stability of immobilized (CL) is higher in comparison to aqueous and immobilized lipase at 70 and $80^{\circ} \mathrm{C}$. Because immobilization and cross linking provided more rigid external backbone for lipase molecules, the effect of higher temperatures in breaking the interactions that were responsible for the proper globular, catalytic active structure, became less prominent, thus increasing the

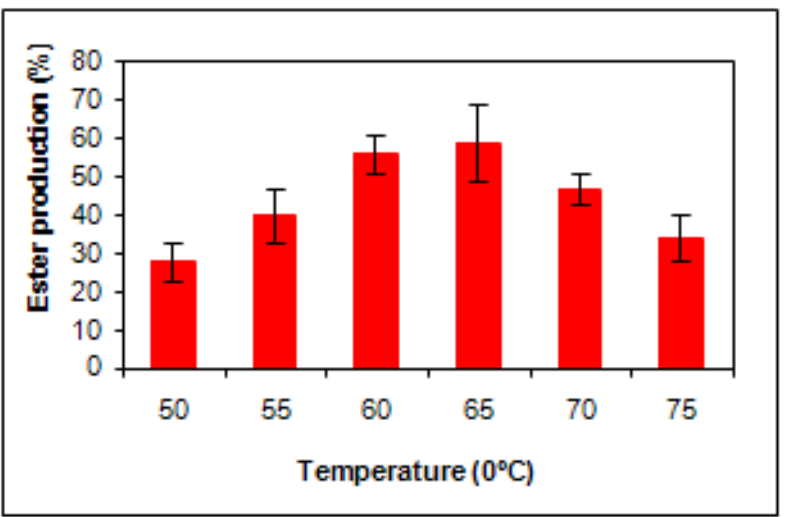

Figure 5. Effect of temperature on esterification of methanol and oleic acid by lipase after $10 \mathrm{hrs}$ of incubation. 
thermal stability of the immobilized lipase. Due to higher thermostability of immobilized cross-linked lipase (CL), HP-20 was used for further studies. It is reported that BTL2 adsorbed on a hydrophobic support exhibited a hyperactivation with respect to the soluble enzyme, whereas the other immobilized preparations suffered a slight decrease in the expressed activity (Palomo et al. 2004). Similar hyperactivation of Rhizomucor miehei lipase was observed by Aucoin et al. by hydrophobic xerogels (Aucoin et al. 2004).

Half-life of aqueous and immobilized lipase (HP-20) was calculated to be $85-90 \mathrm{~min}$ and $4 \mathrm{hrs}$ respectively at $70^{\circ} \mathrm{C}$ (Figure 3). A specific site, where the unfolding process begins during inactivation, characterizes an enzyme. Immobilization protects this unfolding nucleus only in one fraction of enzyme molecule, which could block the native unfolding pathway, resulting in enhanced stability. The second fraction with no protection behaved like a soluble enzyme.

\section{Esterification reaction}

The biosynthesis of esters is currently of much commercial interest because of the increasing popularity and demand for natural products amongst consumer. Biotransformations and enzymatic methods of ester synthesis are more effective when performed in non-aqueous media (Chand et al. 1997). Because of the fact that the present lipases showed much activity and stability in hexane,the esterification of oleic acids and methanol in hexane was carried out.

The effect of incubation time on esterification reaction indicates that ester synthesis was essentially complete by 9 $10 \mathrm{hrs}$ with immobilized enzyme while it took more than 12 hrs with aqueous enzyme (Figure 4). No enhancement in ester production was observed after $10 \mathrm{hrs}$. Fig 5 illustrates the effect of temperature on esterification reaction. During the esterification reaction, water is released as a byproduct and was to be inhibitory to the esterification reaction at a particular concentration (Chand et al. 1997). The higher conversion rate observed in the case isolated lipases here may be explained by the reduction of the water content due to the higher incubation temperature thus decreasing the inhibitory effect of water on esterification reaction. In esterification conditions, one molecule of water is produced when one molecule of acid is esterified. In order to favor this reaction, the produced water must be removed from the medium. Selmi et al. (1997) described temperature increase with air ventilation as one of the possibility. The degree of esterification increased with temperature in the range of $\left(50-70^{\circ} \mathrm{C}\right)$. The reaction declined above $70^{\circ} \mathrm{C}$. Only $18 \%$ conversion was observed at $85^{\circ} \mathrm{C}$. This may be due to the thermal denaturation of enzyme.

For any application based on immobilized lipases, the feasibility of regeneration of the lipase activity (and consequent reuse of the support) provided clear economic benefits for its industrial use. HP-20 beads were comparatively cheap and quite rigid in nature. It had been demonstrated that the immobilization and cross linking of the lipase on HP-20 was advantageous for catalytic property and stability.

\section{REFERENCES}

AUCOIN, Marc G.; ERHARDT, Frank A. and LEGGE, Raymond L. Hyperactivation of Rhizomucor miehei lipase by hydrophobic xerogels. Biotechnology and Bioengineering, March 2004, vol. 85, no. 6, p. 647-655.

BJORKLING, Fredrik; GODTFREDSEN, Sven Erik and KIRK, Ole. The future impact of industrial lipases. Trends in Biotechnology, January 1991, vol. 9, no. 1, p. 360-363.

BOVARA, Roberto; CARREA, Giacomo; OTTOLINA, Gianluca and RIVA, Sergio. Effects of water activity on $\mathrm{V}_{\max }$ and $\mathrm{K}_{\mathrm{m}}$ of lipase catalyzed transesterification in organic media. Biotechnology Letters, September 1993, vol.15, no. 9, p. 937-942.

CHAND, Subhash; ADLERCREUTZ, Patrick and MATTIASSON, Bo. Lipase-catalysed esterification of ethylene glycol to mono and diesters. The effect of process parameters on reaction rate and product distribution. Enzyme and Microbial Technology, February 1997, vol. 20, no. 2, p. 102-106.

CLANS, D. and BERKLEY, W. Genus Bacillus. In: Sheath PHA, Mair NS, Sharpe, H.E. eds. Bergey's manual of systematic bacteriology. Vol. 2. Williams and Wilkins, Baltimore, 1986. p. 1105-1139.

DOSANJH, Nirpjit S. and KAUR, Jagdeep. Immobilization, stability and esterification studies of a lipase from a Bacillus sp. Biotechnology and Applied Biochemistry, August 2002, vol. 36, no. 1, p. 7-12.

FERNANDEZ-LORENTE, Gloria; TERRENI, Marco; MATEO, Cesar; BASTIDA, Agatha; FERNANDEZLAFUENTE, Roberto; DALMASES, Pere; HUGUET, Joan and GUISAN, José M. Modulation of lipase properties in macro-aqueous systems by controlled enzyme immobilization: enantioselective hydrolysis of a chiral ester by immobilized Pseudomonas lipase. Enzyme and Microbial Technology, March 2001, vol. 28, no. 4-5, p. 389-396.

HWANG, Sangpill; AHN, Jungoh; LEE, Sumin; LEE, Tai Gyu; HAAM, Seungjoo; LEE, Kangtaek; AHN, Ik-Sung and JUNG, Joon-Ki. Evaluation of cellulose-binding domain fused to a lipase for the lipase immobilization. Biotechnology Letters, April 2004, vol. 26, no. 7, p. 603605.

JAEGER, K-E.; DIJKSTRA, B.W. and REETZ, M.T. Bacterial biocatalysts: Molecular biology, threedimensional structures, and biotechnological applications of 
lipases. Annual Review of Microbiology, October 1999, vol. 53, p. 315-351.

KIM, Hyung-Kwoun; SUNG, Moon-Hee; KIM, HyoungMan and $\mathrm{OH}$, Tae-Kwang. Occurrence of thermostable lipase in thermophilic Bacillus sp. strain 398. Bioscience, Biotechnology and Biochemistry, 1994, vol. 58, no. 5, p. 961-962.

KLIBANOV, Alexander M. Enzymatic catalysis in anhydrous organic solvents. Trends in Biochemical Sciences, April 1989, vol. 14, no. 4, p. 141-144.

LOWRY, Oliver H.; ROSEBROUGH, Nira J.; FARR, A. Lewis and RANDALL, Rose J. Protein measurement with Folin phenol reagent. Journal of Biological Chemistry, November 1951, vol. 193, no. 1, p. 265-275.

NAWANI, Neerupma; KHURANA, J. and KAUR, Jagdeep. A thermostable lipolytic enzyme from a thermophilic Bacillus sp.: purification and characterization. Molecular and Celularl Biochemistry, 2006, vol. 290, no. 1-2, p. 17-22.

PALOMO, J.M.; SEGURA, R.L.; FERNANDEZLORENTE, G.; PERNAS, M.; RUA, M.L.; GUISAN, J.M. and FERNANDEZ-LAFUENTE, R. Purification, immobilization, and stabilization of a lipase from Bacillus thermocatenulatus by interfacial adsorption on hydrophobic supports. Biotechnology Progress, March-April 2004, vol. 20 , no. 2 , p. $630-635$.

RUA, M. Luisa and BALLESTEROS, Antonio. Rapid purification of two lipase isoenzymes from Candida rugosa. Biotechnology Techniques, January 1994, vol. 8, no. 1, p. 21-26.

SELMI, B.; GONTIER, E.; ERGAN, F.; BARBOTIN, J.N. and THOMAS, D. Lipase-catalyzed synthesis of tricaprylin in a medium solely composed of substrates. Water production and elimination. Enzyme and Microbial Technology, April 1997, vol. 20, no. 5, p. 322-325.

SIGURGISLADOTTIR, Sjöfn; KONRAOSDOTTIR, Malta; JONSSON, Ásbjörn; KRISTJANSSON, Jakob K. and MATTHIASSON, Einar. Lipase activity of thermophilic bacteria from Icelandic hot springs. Biotechnology Letters, April 1993, vol. 15, no. 4, p. 361366.

YANG, Dongsoo and RHEE, Joon Shick. Continuous hydrolysis of olive oil by immobilized lipase in organic solvent. Biotechnology and Bioengineering, September 1992, vol. 40, no. 6, p. 748-752. 